\title{
Psychedelic tourism in Mexico, a thriving trend.
}

\author{
Arturo Laure Vidriales* Diego Hannon Ovies**
}

Universidad de Guadalajara (México)

\begin{abstract}
In this document we showed how a new flow of tourists is arriving in Mexico at alarmingly high rates to experience novel encounters of consumption of psychadelic plants and substances in the tourist industry, despite the lack of a proper organisational structure of tourism, health and safety. We analyse the type of tourists who engages in this activity, using qyualitative research based on interviews with local people in 2016. The results are intereting from the perspective of the immense increase in the peoplef desirous of these new experiences that are offered by the indigenous people.
\end{abstract}

Keywords: Tourism industry; Psychedelic; Neo-shamanism; Neo-colonialism; Decolonization.

\section{Turismo psicodélico en México, una tendencia en crecimiento}

Resumen: En este documento se muestra cómo recientemente un considerable flujo de turistas están llegando a México para experimentar nuevos encuentros en la industria turística, a pesar de la falta de una estructura de atención adecuada en el sector, el consumo de plantas y sustancias psicodélicas entre los turistas modernos está emergiendo en países como México y otros países en América Latina. El propósito de este estudio es demostrar cómo una nueva tipología del turismo está creciendo en México. Los materiales que se utilizaron fueron de carácter cualitativo, además de entrevistas, algunas de estas se aplicaron a la población local en 2016. Los resultados que se encontraron fueron interesantes, debido a la creciente cantidad de personas que quieren experimentar nuevas experiencias alrededor de eco-áreas y también estar en contacto con los pueblos indígenas.

Palabras Clave: Industria turística; Turismo psicodélico; Neo-Chamanismo; Neocolonialismo; Descolonización.

\section{Introduction}

In Mexico there is a wide range of associations, organizations and travel agencies currently offering psychedelic experiences to national and international visitors, this offer generates a significant influx of individuals outside their usual environment, a social phenomenon known as tourism (WTO, 1995). Shamanic practices like psychedelic plant ingestion in indigenous religious contexts are part of an intangible cultural heritage spawning tourist flow in Mexico and South America since the nineteen sixties.

Even though shamanic religious practices were once an essential element of social life in many Mexican prehispanic communities (Hofmann, 1977; De La Garza; Ruiz, 2012) today, most universities, government authorities, and media outlets in the country are completely unfamiliar with such practices.

This widespread unawareness currently merges with an expanding trend of psychedelic-tourism activities, which should be done properly; otherwise two main problems could be generated:

1) Regions lacking proper tourist infrastructure, like the Mexican Wixarika (Tucker, 2017) communities, ${ }^{1}$ are hosting ever growing numbers of tourists. This could be represent an important risk for both host-communities and visitors.

2) Although considered highly attractive by national and international tourists (Demanget, 2001), shamanic practices are usually disregarded by government authorities (World Bank Group, 2014) and developers as potential means for producing social development in Mexican communities.

\footnotetext{
* Departamento de Turismo Recreación y Servicio de la Universidd de Guadalajara, México; E-mail: artlaure@hotmail.com ** Maestrante del programa Ciudad, Territorio y Sostenibilidad por la Universidad de Guadalajara, Mexico; E-mail: diegohannon@hotmail.com
} 
National resources are usually directed towards the establishment and promotion of tourist products like massive beach hotel complexes despite a growing demand for alternative forms of cultural tourism (WTO, 2015).

Through this article intend to raise social and academic awareness on a socially relevant subject that involves a wide international community of travelers which has being completely ignored by tourism academics and developers in Mexico. Controversial topics like environmental depredation (Bocco, 2012), sexual exploitation and drug consumption are closely related to tourism in Mexico so they should be approached by tourism academics in order to properly understand such complex and delicate phenomenon.

As mentioned earlier, is possible to prevent many of the unwanted cultural and environmental consequences produced by this emerging form of tourism, while highlighting its potential benefits and promoting real sustainable development for mexican indigenous communities, or as claimed by Don Juanito, leader of a Wixarika family in Real de Catorce "it is not okay to play around with Peyote (Psyche Plants, 2017), we want tourists to come visit us, but we also want them to know how to consume properly, otherwise is a problem for us" (Milenio, 2013).

\section{Image 1: Location Wixarika Communities}

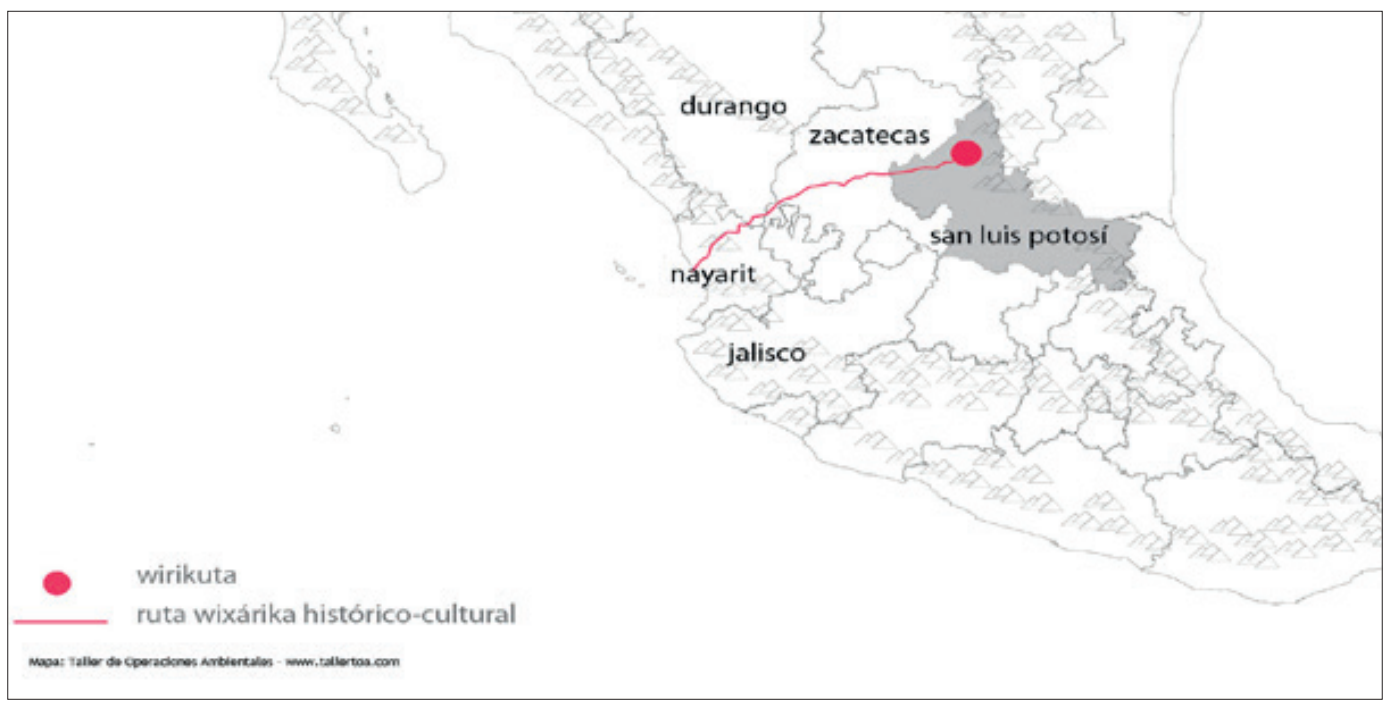

Source: http://venadomestizo.blogspot.com/2013/08/aqui-es-wirikuta.html

\section{Materials}

Most of the information discussed in this study is a qualitative approach, the data collection were gather through secondary data focused the social actors involved in tourism activities, as well as ourselves observations (April 12 2016), also, was taken into consideration how this new wave of tourists want to experience what local people do in rural areas, respecting their traditions, experiences and they own rules.

\subsection{Psychedelics and the western mind.}

The term psychedelic was first coined by British psychiatrist Humphry Osmond, it means "mind manifesting" and is used to describe altered states of consciousness induced by psychoactive plants or chemicals like Ayahuasca, Peyote, psilocybin mushrooms or lysergic acid (LSD). The term was created to replace other terms that fail to describe the wholeness of the psychedelic experience like "hallucinogen" or "psychotomimetic" (Hoffman; Schultes, 1979. p.13), and it was popularized by the hippies during the nineteen sixties.

According to Spanish anthropologist and psychotherapist Joseph M. Fericgla (2013), 89 percent of human civilizations have used psychedelic substances for different religious and sacramental purposes 
the modern western civilization is part of that eleven percent which has left such substances aside, in many cases classifying them as dangerous and illegal. Properly, Thomas B. Roberts (2013), Ph.D professor at Norther Illinois University, claims that we now have the scientific evidence to suggest that medicinal, religious, recreational and dietary use of psychedelic plants, herbs, roots, and mushrooms has taken place among hominids for approximately 5 million years.

Jose Luis Diaz (2015), from the faculty of medicine at the Autonomous University of Mexico (UNAM), asserts that by the sixteenth century, six psychedelic plants had already been identified in the Americas by Spanish Franciscan friar and pioneering ethnographer Bernardino de Sahagun. In his Florentine Codex, Sahagun condemned the use of such plants regarding them as "maddening" and "diabolical", a belief that still prevails among large portions of the Mexican population today.

Ricardo Perez Montfort (2015), from the Center for Research and Advanced Studies in Social Anthropology (CIESAS), located in Mexico, claims that modern science first became interested in the study of mexican psychedelics during the nineteenth century, when German pharmacologist Louis Lewin published the first chemical analysis of the peyote cactus, scientifically known as Lophophora Williamsii, in 1886. At the same time, Danish explorer Carl Lumholtz studied the use of peyote among indigenous groups in the Sierra Madre Occidental, the Mother Mountains of western Mexico.

During the beginning of the twentieth century, Blasius Paul Reko published research work on the classification and use of psychedelics like ololuiuhqui, toloache, peyote, and other medicinal plants used by indigenous groups such as the Aztecs and the Zapotecs (Perez, 2015). However, psychedelic-induced tourism activities would began only after international airports and tourist facilities were built during the nineteen fifties and sixties (Mexican Tourism Policy, 1946), thus allowing the massive arrival of international visitors into the main Latin American cities and subsequently, into some of its indigenous and rural communities, where ancient shamanic traditions were still held despite a strenuous process of colonization.

Since then, psychedelic drug use and modern international tourism have developed conjointly, a delicate relationship that must be carefully analyzed in order to ensure its functional evolution towards a favorable outcome for host communities and outsider participants.

Little research has been done on the subject of psychedelic tourism in Mexico. A study conducted by Alicia Bernard-Mena (1998) addresses the role of indigenous mysticism as motivator for tourism activities in three Mexican destinations: Huautla de Jimenez in Oaxaca, Tepoztlan in Morelos, and Xicotepec de Juarez in Puebla, concluding that the magic and the energy supposedly present in those destinations make them attractive to middle class high-spending national tourists.

It is also important to mention the field research conducted by Vincent Basset in the Wirikuta natural reserve $^{3}$ (2012), in which he tries to analyze and determine the motivations behind mystic-tourists visiting Wirikuta, concluding that a generalized crisis of ideology and identity within the contemporary western world is boosting new forms of tourism, like mystic tourism. (Basset, 2012, p.264)

\subsection{Seeking the magic mushroom. The birth of psychedelic tourism.}

As mentioned earlier, even though the use of psychedelics among indigenous groups has been scientifically studied since nineteen century, it could be hardly argued that the release of Gordon Wasson's article Seeking the Magic Mushroom in Life Magazine in 1957, was the spark that ignited the relationship between modern tourism and psychedelic drug use in indigenous communities. According to the author and journalist Don Lattin (2010):

The richly illustrated article recounts the adventures that Wasson, his Russian-born wife Valentina Pavlouna, and his photographer friend Allan Richardson, had in southern Mexico in the summer of 1955, when they became the first white man in recorded history to eat the divine mushrooms.

Wasson's Russian born wife, Valentina Pavlovna, had a deep academic interest in mushrooms since an early age. When she married Wasson in 1926 -a successful banker working for JP Morgan back then- he also became absorbed in the study of mushrooms, a shared interest that inspired their later adventure into a small indigenous town called Huautla de Jimenez, in the southern state of Oaxaca, Mexico, where guided by Maria Sabina, a local shaman or curandera, they took part in a traditional Mazatec $^{4}$ (National Commission for the Development of Indigenous Peoples, 2007). ceremony which included the consumptions of magic mushrooms ${ }^{5}$, or teonanácatl, as known by the Mazatecs, meaning Divine Flesh or Flesh of God. Detailed recounts of the shamanic ceremony and the attributes of the "magic" Mexican mushrooms were published in the article. (Wasson, 1957) 
James W. Jesso (2013) claims "this article sparked a public awareness, which would later become a near revolution of consciousness within the western world." (p.16). American mycologist Paul Stamets (1998) asserts:

20 million copies of that article showed up in the doorsteps of the households of Americans and wow! It had a big effect; it created a domino interest in the magic mushroom. Popular and academic knowledge of the use of these mushrooms in Mesoamerica was not known until the work of R. Gordon Wasson. (min. 18)

According to Gordon R. Wasson (1980) himself:

As a consequence of my articles published in Life Magazine, a mob of thrill-seekers struck over Huautla de Jimenez... hippies and tourists altering and corrupting the lifestyle of what it used to be an idyllic indigenous town. (p.10)

Correspondingly, ethnobotanist and pioneer researcher in the use of psychedelics Jonathan Ott (2014), claims:

I saw drug-induced tourism on its early stage in the Mazatec Mountains of Oaxaca during the early seventies; I saw its disastrous effects. The idealized vision that Wasson had of Maria Sabina prompted the rebirth of shamanism within the modern world. (min. 4)

Ott explains how the Mazatec culture was, in his opinion, destroyed:

Rock stars began to arrive, bungalows for backpackers or hippietecas were built in the area, post-cards with the image of magic mushrooms were being sold in every corner, supposedly traditional clothing with machine-embroidery designs of mushrooms were a joke... (min.5)

Tourism became so disruptive in the region that it became necessary for government authorities to set up a military checkpoint on the road to Huautla. In his article Tourism and the Multiple Faces of Maria Sabina in Huautla, Oaxaca, Ben Feinberg (2009) talks about what happened to Maria Sabina once tourism boomed in Huautla:

Maria Sabina became a celebrity and many of the visitors, including Rockstars like Bob Dylan, John Lennon, Mick Jagger, and Keith Richards; made special pilgrimages to the mountain top area where she lived. But despite her spreading fame, when she died in 1985 at the age of 91, she was poor and bitter that others had benefited from her name (p. 95).

Maria Sabina has now become a national symbol; restaurants and bars all over Mexico, mainly in the hills of Oaxaca, have been named after her; songs, books and poems about her have been written, t-shirts and posters with her image are sold in hippie markets all over Mexico, and most importantly, national and international tourists are still coming to Huautla and others towns in Oaxaca inspired by the story of Maria Sabina, in order to know the secrets of the magic mushroom.

\subsection{The rise of modern international tourism in Mexico}

The effects produced by tourism in Huautla are no surprise considering that at the same time, a growing international tourism industry was being established in countries like Mexico by international organizations such as the World Bank, the World Tourism Organization and the United Nations, as stated by anthropologist Malcolm Crick (1989):

During the 1960's international tourism was portrayed as a panacea for the less developed countries. The Organization for Economic Cooperation and Development (OECD) spoke of limitless growth potential, the World Bank and the United Nations promoted tourist industries in developing countries. (p.21)

Through loans from the World Bank and the Inter-American Development bank, Mexican tourism authorities established a modern industry which relies mostly on massive sun and beach hotel complexes, all included vacations and timeshare rentals. For example, after hippie tourism boomed in Huautla 
de Jimenez and Puerto Escondido, national tourism authorities became aware of the attractiveness of the state of Oaxaca, according to professor and researcher Catherine Héau Lambert of the National School of Anthropology and History in Mexico (2011):

After 1968 the Mexican Pacific coast of Oaxaca was discovered by the hippies as a paradise. They initiated backpack tourism in the region, but in the 90's, Mexican State constructed there a new city consecrated to mass tourism: Huatulco. To face the regular results of this sort of development, lately the Mexican Government decided to put emphasis on this place as an ecotourism resort. (p.1)

\section{Table \#1: Top 10 of world tourist destinations}

\begin{tabular}{|c|c|c|c|c|c|c|}
\hline \multicolumn{7}{|c|}{ International tourist arrivals } \\
\hline \multirow[b]{2}{*}{ Rank } & & \multirow[b]{2}{*}{ Series } & \multicolumn{2}{|c|}{ (million) } & \multicolumn{2}{|c|}{ Change (\%) } \\
\hline & & & 2015 & $2016^{*}$ & $15 / 14$ & $16 * / 15$ \\
\hline 1 & Franco & TF & 84.5 & 82.6 & 0.9 & -2.2 \\
\hline 2 & Unitod Statos & TF & 77.5 & 75.6 & 3.3 & -2.4 \\
\hline 3 & Spain & TF & 68.5 & 75.6 & 5.5 & 10.3 \\
\hline 4 & China & TF & 56.9 & 50.3 & 2.3 & 4.2 \\
\hline 5 & Italy & TF & 50.7 & 52.4 & 4.4 & 3.2 \\
\hline 6 & United Kingdom & TF & 34.4 & 35.8 & 5.6 & 4.0 \\
\hline 7 & Germany & TCE & 35.0 & 35.6 & 6.0 & 1.7 \\
\hline 8 & Mexico & TF & 32.1 & 35.0 & 9.4 & 8.9 \\
\hline 9 & Thailand & TF & 29.9 & 32.6 & 20.6 & 8.9 \\
\hline 10 & Turkey & TF & 39.5 & .. & $=0.8$ & .. \\
\hline
\end{tabular}

Source: World Tourism Organization

In table 1 it is shown the position where Mexico was located in 2016, 35 million of international visitors went to Mexico for different proposes and one of the typology was ecotourism where some visitors experienced this new wave of psicodelic tourism but there is not certain information yet.

Along with Huatulco a sun and sea destination close to the Sierra Madre Occidental, four other beach destinations were chosen by government authorities as centers for massive tourism development: Cancun, Ixtapa, Los Cabos, Loreto and Huatulco. Since then, tourism development in Mexico has followed purely quantitative growth strategies which exclusively aim at short term profit, thus aggravating social issues like economic inequality while unceasingly degrading the natural environment. (World Bank, 2014)

Although Mexico has vast natural and cultural resources which could be smartly utilized as a tool for establishing a truly sustainable tourism sector, investors and government authorities have repeatedly evidenced their lack of interest for improving social conditions of mexican communities, especially when potential economic benefits are involved, therefore, it is no surprise that, even though Mexico has the richest psychedelic flora in the world (Labate, 2015), national plans of tourism don't even take into account the attractiveness that such traditional indigenous medicine represents, you can't certainly build a thirty-story all-inclusive resort out of a mystical experience.

\subsection{Magic Mushroom Tourism Today}

As mentioned earlier, inspired by the accounts of Gordon Wasson and the teachings of Maria Sabina, many tourists are still traveling to Huautla de Jimenez in Oaxaca in order to find similar experiences. In a blog post that went viral in 2015, Amber Lyon, a former CNN correspondent; reported her experience of "transformation" and "healing" in the southern mountains of Oaxaca:

Curandera Dona Augustine served me a leaf full of mushrooms during a beautiful ceremony before a Catholic alter. As she sang thousand year-old songs, I watched the sunset over the mountainous landscape in Oaxaca and a deep sense of connectivity washed over my whole being. The innate beauty had me at a loss for words; a sudden outpouring of emotion had me in tears. I cried through the night and with each tear a small part of my trauma trickled down my cheek and dissolved onto the forest floor... (para. 16)

Most national and international tourists and backpackers travelling through Oaxaca are aware of regional traditions such as the sacramental consumption of psilocybin mushrooms. In 2014, Vice Magazine filmed a documentary on the use of magic mushrooms in San Jose del Pacifico, a small town in 
the mountains of Oaxaca that has become a popular psychedelic-tourism destination due to its ancient tradition of mushroom consumption. The documentary features an interview with a local hotel owner, Don Leonardo, in which he mentions "we have mushroom tea, dried mushrooms, and mushrooms preserved in honey so tourists don't leave without a trip" (Vice, 2014).

Run by Manuel Garcia Ramirez and Irma Guadalupe Martinez Blas, curanderos with over 35 years of experience in traditional indigenous medicine, the Maliollin Center in San Jose del Pacifico offers services such as weddings, baptizes and magic mushrooms ceremonies in a traditional prehispanic setting. The center provides visitors with a proper care structure that allows participants to rest and integrate the experience.

Despite its international notoriety as a mushroom-tourism destination, San Jose del Pacifico is still a small idyllic town that hasn't yet caught the attention of mass tourism. Hopefully, state and local authorities will be able to prevent later issues regarding tourism growth through proper planning and policy.

In a completely different scenario, Huautla de Jimenez was struck by hippie tourists after the release of Wasson's article in 1957. Consequences produced by tourism in Huautla are still visible until today, according to a field research conducted by Gabriel Eduardo Estrada Martinez in 2009:

Images of Maria Sabina and magic mushrooms are exposed in ashtrays, earrings, napkin holders, beer jars, bags, keychains, $t$-shirts and other tourist merchandise. Supposedly local art crafts are actually made in neighboring towns but are better sold in Huautla, even the local radio station is called "stereo hongo" or stereo mushroom (p.9)

The case of Huautla de Jimenez and Maria Sabina should be used as an example for other psychedelic-tourism destinations, it demonstrates how new forms of tourism can sporadically emerge in the most remote and unlikely regions. Early detection of potential psychedelic-tourism destinations, such as rural and indigenous communities with ancient or living shamanic practices, can help prevent potentially negative consequence as mentioned by Estrada.

Besides Oaxaca, destinations such as Palenque in Chiapas, Senguio in Michoacan and San Pedro Tlanixco in Estado de Mexico, are also popular destinations among psychedelic explorers due to its magic mushroom availability. (Aguilar, 2015). However, very few destinations offer proper care structure for mushroom experiences, such experiences are often undertaken by tourists in beaches, forests or jungles without any guidance or supervision, as for potential risks of consuming magic mushrooms, the Multidisciplinary Association for Psychedelic Studies MAPS (2008) asserts:

Findings in humans and non-human animals indicate that psilocybin (the active chemical ingredient present in Mexican magic mushrooms) has little to no abuse potential. Common acute adverse effects are all psychological and include anxiety or panic response and a prolonged unpleasant experience (or "bad trip"). Studies indicate that psilocybin has very low toxicity. There have been no fatalities directly related to consumption of psilocybin-containing mushrooms.... (pp.48-49).

It is no surprise then, that psilocybin mushrooms have been consumed by indigenous groups around the world for thousands of years. Recently, the University of South Florida published a study asserting that psilocybin has the ability to grow new brain cells. Researchers found that psilocybin relieved or even cured depression and post traumatic stress disorder or PTSD, while repairing damaged brain cells in mice. (Catlow, Song, Paredes, Kirstein, Sanchez-Ramos, 2013), also, Roland Griffiths from the Johns Hopkins University School of Medicine, conducted a study in which it was shown how psilocybin can induce mystical-religious experiences "having substantial and sustained personal meaning and spiritual significance" (Griffiths, 2006, p. 1).

\subsection{Peyote tourism in the Wixarika context}

In a similar case, the sacramental ingestion of the Peyote cactus by indigenous groups has been a subject of interest among western researchers and explorers for centuries. The cactus is native to Mexico and southern parts of the United States. According to Rojas-Arechiga and Joel Flores:

Widely adopted for its therapeutic and visionary properties since pre-Hispanic times, this species has always been controversial; to some it was considered the devil's plant, and to others, the gods'plant... it has obsessed not only scientists, but also writers and enthusiasts (2016). 
One of the founding fathers of ethnopharmacology, Dr. Richard Evans Schultes claims "most important writings on Peyote were made by Bernardino de Sahagun in the sixteenth century" (Schultes, 1979, p. 145). Schultes also claims that "specimens found in a context that suggests ceremonial consumption, indicate that peyote has being used for over 7,000 years." (p.145)

In 1968, a book written by Peruvian-born American anthropologist Carlos Castañeda, The Teachings of Don Juan was released to the public. In the book, Castañeda explains the process of shamanic training he underwent guided by an old Yaqui Shaman named Don Juan Matus, as reported by Castañeda himself:

When I was dedicated to pursue my graduate studies in the Department of Anthropology at the University of California, by chance I met an old shaman, a Yaqui Indian from the state of Sonora, Mexico. His name was Juan Matus. (1974, p.33)

The book, which sold more than 8 million copies in 17 languages, also elaborates on the sacramental use of Peyote (Lophora williamsii), or mezcalito, as supposedly named by Don Juan. During the seventies, the popularity of Castaneda's work sparked tourism in Real de Catorce and the Wirikuta reserve, however, unlike Peru and Brazil, where psychedelic tourism is institutionalized and regulated under strict legal standards, in Mexico, Peyote tourism is still unregulated and in most cases illegal, according to Vincent Basset (2012):

Tourist activities that re-build new shamanic rituals of peyote consumption have generated many conflicts between native Indians (Wixarica), locals, and drug policy agents in this natural reserve. (p.6)

Regarding the legal status of the Peyote cactus, researches Labate and Feeney assert (2016):

Peyote is considered a species requiring "special protection" due to environmental concerns; peyote is also protected under the Convention on the International Trade in Endangered Species (CITES). In 1984, peyote was added to Mexico's national list of controlled substances, in 2009, an exemption was introduced to protect traditional indigenous uses of peyote. (p.1)

However, "challenges, paradoxes, and ambiguities are still present in the current regulatory framework addressing possession and use of peyote". (Labate, Feeney, 2016, p.7). The lack of policies regarding the use of Peyote has only hindered the development of a functional tourism sector that could significantly improve the living conditions of the Wixarika communities, since it can be a source of income and at the same time is preserved and highlights its traditions.

Just recently, the Human Rights Commission of the state of Aguascalientes granted the right of consumption to Wixarika communities established in the state (Acero, 2016), likewise, a legal request presented by the Native American Church of Mexico (INAM) seeks to obtain legal permission to use Peyote based on the principle of religious freedom. According to one of its members, Cynthia Espinola, "there are over 5,000 people in Mexico who profess this rite, including people from all walks of life, although many people do not want to admit it publicly" (CNN, 2015).

\subsection{Ayahuasca ceremonies in Mexico}

Another traditional psychedelic substance that is now been widely used among modern westerners in Mexico is Ayahuasca (Seer, 2017). Native to the South American Amazon jungle, where it has been sacramentally ingested by Amazonian indigenous groups for thousands of years, Ayahuasca has triggered mass tourism in indigenous communities in Brazil, Peru, Ecuador, Colombia, Bolivia, Venezuela, and has now spread to the rest of the world, including Mexico, the United States, Canada and Europe where religious groups, clinics and centers offering Ayahuasca ceremonies and retreats have flourished during the last decade. (Stuart, 2002; Fotiou, 2010)

Also called a yagé, Ayahuasca is a beverage, some say it's a brew, others say a tea; made up of a mixture of a leaf Banisteriopsis caapi and a second plant which can either be Psychotria viridisor, or Diplopterys cabrerana, plants containing high amounts of DMT, a naturally occurring psychedelic compound found in many plants and animals that is also produced in the human brain (Schultes, 1979). The website ayahuascainfo.com affirms: 
Ayahuasca is capable of inducing altered states of consciousness, usually lasting between 4 to 8 hours. Ranging from mildly stimulating to extremely visionary, ayahuasca is used primarily as a medicine and as a shamanic means of communication, typically in a ceremonial session under the guidance of an experienced drinker. The earliest Europeans to mention Ayahuasca were Jesuits travelling in the Amazon. One of the earliest such reports of this "diabolical potion," written in 1737, describes it as: "an intoxicating potion ingested for divinatory... which deprives one of his senses and, at times, of his life."

The brew was first discovered by modern science in 1851, when British botanist Richard Spruce collected samples of the caapi leaf, used by native amazon tribes such as the Vaupes in Brazil and the Zaparos from Ecuador (Schultes, 1979), however, according to Dennis Mckenna (1998):

Credit for the earliest published reports of ayahuasca usage belongs to the Ecuadorian geographer Manuel Villavicencio, who, in 1858, wrote of the use of ayahuasca in sorcery and divination on the upper Rio Napo. (p.3)

Ayahuasca has recently reached Mexico, where centers offering supervised ceremonies are sparking in the main cities and their surroundings, for example, in the city of Guadalajara, Shikoba-Home offers Ayahuasca and Peyote supervised ceremonies every two weeks for a price of 1500 Mexican pesos per person or approximately 80 US dollars. In Facebook, the Mexico City Ayahuasca group, in which ceremonies and talks are promoted, has 32,425 followers. Another organization called Ayahuasca Mexico Jaguar Negro has 39,304 followers on its facebook page, they also offer supervised ceremonies around the country.

\section{Motivations behind psychedelic Tourism}

Despite the lack of statistics regarding the amount of tourists traveling to Mexico to consume psychedelics, three main factors evidence this growing new trend of psychedelic tourism in Mexico and many parts of the world (Grunwell, 1998):

1) The amount of clinics, centers and travel agencies offering supervised psychedelic experiences has boosted during the past 10 to 15 years.

2) The amount of scientific studies, books, documentaries, media reports, conferences, talks and events approaching the subject has also significantly increased during the last 10 to 15 years.

3) Scientific, social and environmental organizations, associations and institutions addressing the subject of psychedelics from different perspectives have multiplied around the country.

Furthermore, we can identify two main trends on psychedelic tourism in Mexico:

1) Tourists from main urban centers are increasingly traveling to indigenous communities, where psychedelic plants are ingested as part of their religious rituals, with the purpose of actively participating in such religious rituals. (Such as the cases of Peyote-tourism in the Wixarika communities and magic mushroom-tourism in Oaxaca).

2) Due to increased demand, which is driven by the spread of information; centers, clinics and retreats that provide psychedelic medicines are thriving.

It is important to mention that not all centers, clinics and retreats offering psychedelics are located in indigenous communities, a good amount of them are located in the main urban centers of Mexico, nevertheless, psychedelic tourism in indigenous communities, like the Wixarika and the Mazatec, is also increasing at alarming rates.

So what is driving so many tourist towards these unknown experiences? One of the main reasons, as claimed by Katie Bain (2015) in an article published in LA Weekly:

Plant-based "entheogens" (a term meaning "of god" and referring to psychedelic substances that typically cause a sort of spiritual awakening) are showing promise in the treatment of conditions including addiction, anxiety, depression, trauma, eating disorders and chronic pain. (para. 8)

The need for a temporary escape, which is the need to break the daily routine shared by individuals living in complex urban societies, now merges with a growing spread of information about the healing properties of psychedelics, along with the weakening of major contemporary religions and other inherent 
aspects to urban lifestyle, like financial and social pressure, alienation, stress, depression and anxiety; all these factors are currently coming together to push tourists outside their cultural norms towards these culturally unknown experiences. (Andrade, Gabriel, 2002)

Tourism researcher and author Malcom Crick (1989) claims "to be a tourist is to opt out of ordinary social reality, to withdraw from everyday adult social obligations" (p.33), correspondingly, philosopher Jason Silva (2012) claims that traveling and consuming psychedelics are equivalent activities:

Psychedelics pull us so rapidly out of our comfort zones they decondition our thinking, they change our context in order to see things as if for the first time, that's why people call it "take a trip", look a the physical equivalence of that, taking a trip means physically going to a place you've never been before, see the world differently, jump into a new culture...

Vincent Basset (2012) has studied the motivations behind peyote induced tourism in the Wirikuta reserve, he claims:

In the ongoing search for new sensory experiences, using means like the internet to exchange information, influenced by sensationalist shamanic writings; psichonauts ${ }^{6}$ multiply their psychedelic experiences in order to increase their level of understanding and knowledge of the world.

One of the most influential authors on the subject of psychedelics, Aldous Huxley, asserts in his acclaimed essay The Doors of Perception (1956) "the desire to escape and to transcend oneself and its environment is present in most of us most of the time." (p.58). Such desire has not only prompted the worldwide consumption of alcohol, tabaco and other drugs, but it also triggers modern tourism activities, which similarly to drugs, are one of the main means preferred by western individuals to induce that feeling of temporary escape from daily hustle.

\subsection{Is psychedelic tourism neocolonialism or decolonization?}

When trying to describe the social profile of the psychedelic-tourist or "psychonaut" (explorer of the psyche), Basset addresses:

This type of tourist tends to overestimate the figure of the Amerindian, elevating them to the rank of authentic Indian, thus regarding them as the redeemer of the white man... this phenomenon of rediscovery and reappropriation of native shamanism represents, for the tourist, the possibility of transcultural communication through which his/her "identity" undergoes some form of transformation. (p. 246)

In an article published by the Central University of Colombia, anthropologist Alhena Caicedo talks about an emerging social phenomenon "the re-appropriation and re-semantization of therapy practices of indigenous origin" (p.114) by western individuals from urbanized societies, a phenomenon known among anthropologists as neo-shamanism. Joseba Arregi (2011) describes tourism motivated by neoshamanism as the colonization of indigenous exoticism, he also adds, "this phenomenon has to do with a historical feature among white Americans that leads them to idealize the indigenous" (para. 9). During its article, Arregi quotes indigenous activist Janet McCloud:

First they came to take our land and water, then our fish and game... Now they want our religions as well. All of a sudden, we have a lot of unscrupulous idiots running around saying they're medicine people... It's not only wrong, it's obscene. Indians don't sell their spirituality to anybody, for any price. (para. 8)

Additionally, Arregi claims that tourism motivated by shamanic practices like psychedelic consumption is also closely linked to a growing social movement known as New Age, which similarly to neoshamanism, it incorporates Buddhist, Hinduist, and indigenous elements and practices like yoga, meditation, vegetarianism and psychedelic drug use into modern western societies. Arregi and others condemn such forms of cultural misappropriation arguing that:

The activity of plastic shamans and their followers has generated enormous concern... indigenous leaders like Russell Means and scholars like Vine Deloria, or Ward Churchill have unmasked this new form of colonization. (para. 18) 
Contrarily, Johnathan Ott (2014) opposes to any form of tourism in indigenous communities, arguing that visitors inevitably do more harm than good to communities and their fragile cultures and environments, on the other hand, ethnopharmacologist Dennis McKenna (2014) believes tourism can be properly utilized to protect indigenous communities and their traditions from menacing industries like agriculture, mining and logging.

As a measure to mitigate the negative impacts caused by psychedelic tourism, Ott himself proposes the promotion of educational guide-books and manuals that allow tourists to identify native psychedelic plants which can be consumed in their own environments without touring into fragile indigenous communities; however, as we are currently witnessing, broadcasting information about psychedelics is not holding tourists back from traveling to indigenous communities where such substances are consumed, but its actually doing the very opposite, by igniting curiosity among westerners who find themselves tired and bored of conventional forms of religion.

The fact that psychedelic tourism is internationally thriving can be opposed but it can not be stopped. To oppose such inevitable social phenomena only hinders its functional development towards a favorable outcome for host communities and outsider participants.

Conflicts and difficulties will emerge along the road, but obstacles will be better overcome if agents involved facilitate and advise the process of integration between the two phenomena involved in the equation, tourism and psychedelic drug use, instead of simply opposing such process.

In October 2015, the first Congress on Drugs, Politics and Culture Mexico-Brazil, was carried out in the Center for Research and Advanced Studies in Social Anthropology CIESAS. One of the main conferences was given by Brad Burge, from the Multidisciplinary Association for Psychedelic Studies, during his talk, Burge mentioned:

An important vision of MAPS'vision for the legalization of the medical uses of psychedelics is the creation of a network of clinics, much like ibogaine clinics in Mexico today, where patients can receive legal psychedelic therapy together with preparation and integration services.

In a similar position, the Ethnobotanical Stewardship Council, "is dedicated to transforming lives through assuring the safety and sustainability of traditional plants" (Wickerham, 2014). During the World Ayahuasca Conference, organized annually in Spain, ethno-pharmacologist Dennis McKenna (2014) also approached the subject of sustainability, he believes neo-shamanism has actually helped rescue and preserve indigenous traditions that would have vanished otherwise, he also stressed the need to ensure cultural, environmental and economic sustainability for host communities. In a similar position, the national Secretariat for Tourism in Mexico, SECTUR (2012), has already established plans and methodologies for tourism destinations whose goal is "to generate sustainable development through tourism activities and to increase the quality of life in host-communities."

While tourism authorities in Mexico are still focusing most of their efforts and resources on the promotion and development of mass tourism products such as all-inclusive resorts, Disneyland style parks and apartment towers (Clancy, 2001; Gómez, 2005), a growing segment of the tourist international market is demanding experiences which can provide them with a deep sense of personal transformation and awe-inspiring moments that go far beyond the conventional resort experience. (Cohen, 2005; CREST, 2015). Attractive cultural resources like shamanic indigenous traditions and their ancient medicines could be otherwise utilized not only to satisfy such demand, but to really diversify national tourism offer, thus increasing international competiveness, while promoting and achieving legitimate sustainable development for rural and indigenous communities, just as Brazil, Peru, Colombia and Ecuador are already doing ${ }^{7}$ (The Yucatan Times, 2015).

A functional integration between tourism and psychedelic drug use can only be achieved through an interinstitutional-multidisciplinary approach which will require cooperation among public and private sectors, government authorities, social-scientific organizations, and high-education institutions.

The relationship between tourism and psychedelic-consumption will continue to grow as long as the subject remains as a trend topic among academics and media outlets, therefore, specific plans and methodologies of diagnose and development for mexican psychedelic-tourism host-communities, like San Jose del Pacifico or Real de Catorce, will have to be developed during coming years if consequences such as those presented in Huautla de Jimenez want to be prevented.

The failure of the fight on drugs which has severely punished Mexican rural and indigenous communities, can only be amended through regulation and education. As a society we can't keep denying our 
reality while hiding our own traditions under the rug. As recently claimed by Brazilian anthropologists Bia Labate (2015), from the Center for Research and Advanced Studies in Social Anthropology:

Mexico has the richest psychedelic flora in the world, we are sitting on a treasure. Why is this issue not being researched? Why isn't there a public debate on the issue? Why this subject is not on the national agenda? Why Mexicans don't want to recognize their own authentic indigenous roots and traditions?

\section{Final reflections.}

Nowadays, tourists are different from the beginning of the 20th. century, they are informed, want to experience new things away from the mass tourism, they want to experience what local people do, especially in rural areas; if addressed properly, that is from a multidisciplinary scientific approach, psychedelic tourism can be used to protect and preserve indigenous communities and their resources from voracious industries like mining, logging and large-scale agriculture, otherwise, if allowed to develop without supervision, consequences produced by this delicate new form of tourism can be disastrous not only for host-communities and their culture, but for outsider visitors as well.

It is important to carefully analyze this rapidly growing trend in order to provide society with objective information about the risks and benefits of these practices which not by chance have been present among indigenous traditions around the world for thousands of years. In addition, a carefully devised analysis facilitates understanding the value and significance of the different elements comprising the relationship between tourism and psychedelic drug use, thus raising awareness to deal objectively with an issue that stands out due to its complexity and diversity of forms and manifestations.

\section{Bibliography}

Acero, I.

2016. Permiten a pueblos indígenas uso y transporte de peyote. La Jornada. Retrieved from: http:// www.lja.mx/2016/01/permiten-a-pueblos-indigenas-uso-y-transporte-de-peyote/

Aguilar, M.

2015. Lugares para probar hongos alucinógenos. Cultura Colectiva. Retrieved from: http://culturacolectiva. com/lugares-para-probar-hongos-alucinogenos/

Alper, K.

2001. Alkaloids Chem Biol. Retrieved from:

http://www.sciencedirect.com/science/article/pii/S0099959801560058.

Arregi, J.

2011. Chamanes de plástico, colonialismo intelectual y apropiación intelectual entre movimientos de nueva era. EUMED. Retrieved from: http://www.eumed.net/rev/cccss/12/jia2.htm

Bain, K.

2015. Meet magic mushroom, ayahuasca and ibogaine enthusiasts at L.A's first visionary convergence. LaWeekly. Retrieved from: http://www.laweekly.com/arts/meet-magic-mushroom-ayahuasca-and-ibogaine-enthusiasts-at-las-first-visionary-convergence-6089924

Barsuglia, J.

2016. Psychedelic Research with Ibogaine and 5-MeO-DMT: An Interview with Dr. Joseph Barsuglia. West T. (Eds.) PsychedelicTimes.com. Retrieved from: http://psychedelictimes.com/iboga/psychedelic-research-with-ibogaine-and-5-meo-dmt-an-interview-with-dr-joseph-barsuglia/

Bastianns, E.

2004. Life after Ibogaine. An exploratory study of the long-term effects of ibogaine treatment on drug addicts. Science Internship Report. Vrije Universiteit Amsterdam. Faculty of Medicine. Retrieved from: http://www.ibogaine.desk.nl/ibogaine_udi_bastiaans.pdf

Bernard-Mena, A.

1998. Turismo mistico-esoterico en México. Estudios y Perspectivas en Turismo. Retrieved from de http:// www.estudiosenturismo.com.ar/search/PDF/v7n3y4.pdf

Bocco, G.

2014. Centro de Investigaciones en Geografía Ambiental de la UNAM. Retrieved from http://www. sinembargo.mx/29-02-2012/165749 
Broze, D.

2015. From Psilocybin to MDMA: Researchers Are In the Throes of a Psychedelic Revival. Mint Press News. Retrieved from: http://www.mintpressnews.com/from-psilocybin-to-mdma-researchers-are-in-the-throes-of-a-psychedelic-revival/210550/

Burge, B.

2015. The psychedelic science and medicine in the xxi century. Drogas Mexico-Brasil. Multidisciplinary Association for Psychedelics Studies. MAPS. (Eds.) Horacio Guevara. Retrieved from: http://drogasmexicobrasil.mx/index.php/2015/10/15/the-psychedelic-science-and-medicine-in-the-xxi-century/

Castañeda, C.

1974. Las enseñanzas de Don Juan. México. Fondo de Cultura Económica.

CDI [Comisión Nacional para el Desarrollo de los Pueblos Indígenas]

2004-2007. "Mazatecos - Ha shuta Enima". Información: Los pueblos indígenas de México (in Spanish). CDI. Archived from the original on 2007-06-09. Retrieved 2007-05-02.

Clancy, M.

2001. Exporting Paradise: Tourism and Development in Mexico. New York: Pergamon.

$\mathrm{CNN}$

November, 2015. El peyote va por el camino legal de la marihuana. Retrieved from: http://www. cnnexpansion.com/economia/2015/11/11/el-peyote-va-por-el-camino-legal-de-la-marihuana

Cohen, E.

2005. Major trends in contemporary tourism. The Hebrew University of Jerusalem. Department of Sociology and Anthropology. Retrieved from. http://revistas.ucm.es/index.php/POSO/article/view/ POSO0505130011A/22986

Crest

2015. The Case for Responsible Travel: Trends and Statistics. Retrieved from https://ecotourism.app. box.com/s/rxiyp65744sqilmrybfk8mys3qvjbe9g

Crick, M.

1989. "Representations of International Tourism in the Social Sciences. Apostolopoulos (pp. 15-43)"., Y., Leivadi, S. \& Yiannakis, A. (Eds.), Sociology of Tourism. New York: Routledge

De la Garza, R; Ruiz, M. Sueño y éxtasis visión.

2012. Chamánica de los Nahuas y los Mayas. México. Universidad Nacional Autónoma de México. Instituto de Investigaciones Filológicas. Fondo de Cultura Económica.

Demanget, $\mathrm{M}$.

2001. Reconstruction of the shamanic space and mystical tourism in the Mazatec region (Mexico), Biblioteca shamanistica - ISSSR, $n^{\circ}$ 10, 2001, p. 305-330, Articles et actes dans des colloques et chapitres d'ouvrages,

Esquivel, S.

2014. Terapia ancestral del sapito otac (bufo alvarius) de Sonora, México con el Dr. Octavio Retting Hinjosa en Valencia (Trincheras). Retrieved from: http://allevents.in/events/terapia-ancestral-del-sapito-otac-bufo-alvarius-de-sonora-m\%C3\%A9xico-con-el-dr-octavio-rettig-hinojosa-e/628085833881073 Estrada, M.

2009. El cambio sociocultural del rito en el consumo de hongos alucinógenos en Huahutla de Jiménez, Oaxaca: de los fines curativos a los lúdicos para su comercio. Mind Suf. Retrieved from: http://www. mind-surf.net/drogas/peyote/Ponencias/Gabriel\%20Estrada\%20cambio\%20sociocultural\%20del\%20 rito.pdf

Feinberg, B.

2009. A Symbol of Wisdom and Love? Counter-Cultural Tourism and the Multiple Faces of Maria Sabina in Huautla, Oaxaca. Retrieved from: https://books.google.com.mx/books?id=s--lFZ5RKwcC\&pg=PA93\&lpg=PA93\&dq=Tourism+and+the+Multiple+Faces+of+Maria+Sabin $\mathrm{a}+\mathrm{en}+$ Huautla\&source=bl\&ots=fhLU9s YFkI\&sig $=6 \mathrm{GuZ1}$ pjta4klBhDhSCoRcQn $3 \mathrm{bLs} \& \mathrm{hl}=\mathrm{es}-$

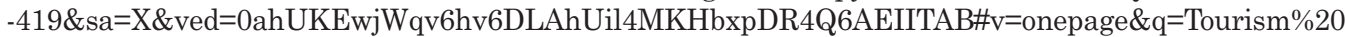
and\%20the\%20Multiple\%20Faces\%20of\%20Maria\%20Sabina\%20en\%20Huautla\&f=false

Grunwell, J.

1998. Ayahuasca Tourism in South America. Newsletter of the Multidisciplinary Association for Psychedelic Studies (8). pp. 59-62. Retrieve from: https://www.maps.org/news-letters/v08n3/08359gru.html Gómez, S.

2005. El Desarrollo Turístico Imaginario. Ensayos sobre un destino mexicano de litoral. Universidad de Guadalajara. Retrieve from: http://www.cuc.udg.mx/sites/default/files/publicaciones/2015\%20-\%20 Desarrollo,\%20crisis\%20y\%20turismo.pdf 
Griffiths, R. et al.

2006. Psilocybin can occasion mystical-type experiences having substantial and sustained personal meaning and spiritual significance. Springer-Verlag. DOI 10.1007/s00213-006-0457-5. Retrieved from: http://www.csp.org/psilocybin/Hopkins-CSP-Psilocybin2006.pdf

Héau, C.

2006. El ecoturismo como sustitio problemático de las responsabilidades redistributivas del estado. Revista Nuevas Tendencias en Antropología. Escuela Nacional de Antropología e Historia - México. Retrieved from: http://www.revistadeantropologia.es/Textos/N2/El\%20ecoturismo\%20como\%20 sustituto\%20problematico.pdf

Hofmann, A. Preface. Moksha. Aldous Huxley's Classic Writings on Psychedelics and the Visionary Experience. Michael Horowitz \& Cynthia Palmer (Eds.) Park Street Press. Rochester, Vermont.

Huxley, A.

2014. Las puertas de la percepcion. Cielo e infierno. Editores Mexicanos Unidos.

Jesso, J.

2013. Decomposing the shadow. Lessons from the psilocybin mushroom. Calgary: SoulsLantern Publishing.

Labate, B.; Clancy, C.

2016. Summary. Peyote: History, Traditions, Politics, and Conservation. Drogas Mexico Brasil. Retrieved from: http://drogasmexicobrasil.mx/wp-content/uploads/2016/01/Summary-English.pdf

Lyon, A.

2014. How psychedelics saved my life.Reset.me. Retrieved from: http://reset.me/story/howpsychedelicssavedmylife/

Mckenna, D.

AYA2014 - Sustainability: Dennis McKenna, Roldan Rojas, Rick Doblin, Joshua Wickerham. ICEERS. [Video Archive]. 2014. Retrieved from: https://www.youtube.com/watch?v=l4lrRFE1mz4

Mexican Tourism Policy

1946. El Turismo en México, pg. 46. . Retrieved from: http://catarina.udlap.mx/u_dl_a/tales/documentos/ lri/linares_c_c/capitulo2.pdf

Oroc, J.

2009. Tryptamine Palace: 5-MeO-DMT and the Sonoran Desert Toad. Park Street Press. Rochester, Vermont.

Palhano, F; Alchieri, J.C; Oliveira, J.P.

2013. The Therapeutic Potentials of Ayahuasca in the Treatment of Depression. Springer Berlin Heidelberg. Retrieved from: http://link.springer.com/chapter/10.1007/978-3-642-40426-9_2

Polanco, M.

October, 2016. Ibogaine: Dr. Martin Polanco Talks Psychedelic Therapy for Addiction. Psychedelic Times. Wes T. Retrieved from: http://psychedelictimes.com/iboga/ibogaine-5-meo-dmt-dr-martin-polanco-talks-psychedelic-therapy-for-addiction/

RESET.ME. How psychedelics are saving lives. Video Igniter.2014,MAY 1. [Video Archive]. Retrieved from: https://www.youtube.com/watch?v=3uqBGTnUukg

Roberts, T; Winkelman, M.

2013. Psychedelic Medicine. Gaia Medicine. [Video Archive] Retrieved from: https://www.youtube.com/ watch?v=SlQZy9-KagY

Rojas, M; Flores, J.

2016. An overview of cacti and the controversial peyote. (Eds.) Summary: Peyote: History, Traditions, Politics, and Conservation. Beatriz Labate and Clancy Cavnar. Retrieved from: http://drogasmexicobrasil.mx/wp-content/uploads/2016/01/Summary-English.pdf

Rowse, A.

2012. The boom of Ibogaine clinics in Mexico. WordPress. Retrieved from: https://ibogainebest.wordpress. com/2012/05/18/the-boom-of-ibogaine-clinics-in-mexico/

Ruiz, P. J. Chamanismo.

2006. Puerta entre dos mundos. FAPA Ediciones.Barcelona, Spain.

Santos R.G; et al.

2007. Effects of ayahuasca on psychometric measures of anxiety, panic-like and hopelessness in Santo Daime members. Journal of Ethnopharmacology. Vol. 112 , P. 507-513. Retrieved from: http://www. sciencedirect.com/science/article/pii/S0378874107002139

Schultes, R.E; Hofmann, A.

1979. Plantas de los Dioses. Fondo de Cultura Económica. 
Seer, B.

2017. The Beginner's Guide to Ayahuasca Healing. Retrieve from: https://entheonation.com/blog/ ayahuasca-healing-guide/

SECTUR. Programa de Turismo Sustentable en Mexico.

2012. Retrieved from: https://www.google.com.mx/url?sa=t\&rct=j\&q=\&esrc=s\&source=web\&cd=1\&ca $\mathrm{d}=$ rja\&uact=8\&ved=0ahUKEwjr97Cq-7HLAhXB4SYKHRl_BCgQFggaMAA\&url=http $\% 3 \mathrm{~A} \% 2 \mathrm{~F} \% 2$ Fwww.sectur.gob.mx\%2FPDF\%2Fplaneacion_estrategica\%2FPTSM.pdf\&usg=AFQjCNFZD9ZFc10 wf65Pm3AApNlwFk6_sw\&sig2=WOLRqui2_avIRFSfdfH8hQ

Shroomery.

2004. Psilocybe Toxicity Information. Shroomery.org. Retrieved from: https:/www.shroomery.org/6297/ Psilocybe-Toxicity-Information

Tupper,K. W.

2006. The globalization of ayahuasca: Harm reduction or benefit maximization? International Journal of Drug Policy doi:10.1016/j.drugpo.2006.11.001. Retrieved from: http://www.encod.org/info/IMG/ pdf/Ayahuasca.pdf

World Bank Group

2014. La pobreza rural en México. Pg 69. Retrieved from: http://siteresources.worldbank.org/INTMEXICO/ Resources/La_Pobreza_Rural_en_Mexico.pdf

World Tourism Organization

2015. Affiliate Members Global Reports, Volume twelve - Cultural Routes and

Itineraries, UNWTO, Madrid.

WTO

1995. Technical manual: Collection of Tourism Expenditure Statistics. Ginebra: World Tourism Organization.

\section{Notes}

1 The Huichol, Wixáritari, or Wixárika, are indigenous Mexicans living in the Sierra Madre Occidental range in the states of Nayarit, Jalisco, Zacatecas, and Durango, and are recognized for having preserved their spiritual identity.

2 Real de Catorce is a small town in the Mexican state of San Luis Potosí which has long been a pilgrimage site for local Wixarika shamanists, and since the seventies, for national and international tourists as well.

3 Wirikuta is one of the most important natural sacred sites of the Wixárika people, in 1988 it was incorporated by UNESCO to the World Network of Natural Sacred Sites.

4 The Mazatec people are an indigenous people who inhabit an area known as the Sierra Mazateca in the state of Oaxaca in southern Mexico, as well as some communities in the adjacent states of Puebla and Veracruz.

5 Psilocybin mushrooms (Psilocybe Mexicana), also known as "magic mushrooms", have been consumed by the Mazatec indigenous people of Oaxaca as part of their religious tradition for centuries.

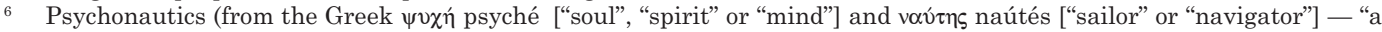
sailor of the soul" refers both to a methodology for describing and explaining the subjective effects of altered states of consciousness, including those induced by meditation or mind-altering substances, and to a research paradigm in which the researcher voluntarily immerses himself or herself into an altered mental state in order to explore the accompanying experiences. A psichonaut is person who scientifically investigates altered states of consciousness, sometimes to the extent of taking measurements and keeping records of experiences. (Wikipedia, 2015)

7 Brazil, Peru, Colombia and Ecuador have all developed national and regional plans of alternative forms of tourism such as rural tourism, cultural tourism, community tourism, and the different forms of psychedelic tourism, through which indigenous communities have been able to produce complementary earnings and improve their lifestyles while attracting high-spending tourists and scientists from all over the world. 